\title{
Symposium review: Genetics, genome-wide association study, and genetic improvement of dairy fertility traits*
}

\author{
L. Ma, ${ }^{1} \dagger$ J. B. Cole, ${ }^{2}$ Y. Da, ${ }^{3}$ and P. M. VanRaden ${ }^{2}$ \\ ${ }^{1}$ Department of Animal and Avian Sciences, University of Maryland, College Park 20742 \\ ${ }^{2}$ Henry A. Wallace Beltsville Agricultural Research Center, Animal Genomics and Improvement Laboratory, ARS, USDA, Beltsville, \\ MD 20705-2350 \\ ${ }^{3}$ Department of Animal Science, University of Minnesota, St. Paul 55108
}

\section{ABSTRACT}

Before fertility traits were incorporated into selection, dairy cattle breeding primarily focused on production traits, which resulted in an unfavorable decline in the reproductive performance of dairy cattle. This reduced fertility is constantly challenging the dairy industry on the efficiency and sustainability of dairy production. Recent development of genomic selection on fertility traits has stabilized and even reversed the decreasing trend, showing the effectiveness of genomic selection. Meanwhile, genome-wide association studies (GWAS) have been performed to identify quantitative trait loci (QTL) and candidate genes associated with dairy fertility, providing a better understanding of the genetic architecture of fertility traits. In this review, we provide an overview of the genetics of fertility traits, summarize the findings from existing GWAS of female fertility in dairy cattle, and update the recent research progress in US dairy cattle. Because of the polygenic nature of fertility traits, many GWAS of dairy fertility tended to be underpowered. Only 1 major QTL, on BTA18, was identified across multiple studies. This QTL was associated with a range of fertility traits from conception to calving, but the candidate gene or mutation is still missing. Collectively, with the promising success from genomic selection but low power of GWAS on dairy fertility traits, this review calls for continuous data collection of fertility traits to enable more powerful studies of dairy fertility in the future.

Key words: fertility, dairy cattle, genome-wide association study, genomic selection

Received June 23, 2018.

Accepted August 16, 2018.

*Presented as part of the Breeding and Genetics Symposium: Fertility - Filling the Gaps at the ADSA Annual Meeting, Knoxville, Tennessee, June 2018.

†Corresponding author: lima@umd.edu

\section{INTRODUCTION}

For more than 40 yr until 2002, increases in Holstein milk production were accompanied by declines in female fertility, as shown by the genetic trends for milk yield and daughter pregnancy rate in Figure 1 (Hansen et al., 1983; de Vries and Veerkamp, 2000; Royal et al., 2000; Hayes et al., 2009). This trend has only recently leveled out and begun to improve (García-Ruiz et al., 2016). Successful conception in Holstein cows now requires approximately $50 \mathrm{~d}$ longer than it did 50 yr ago $(-1 \%$ daughter pregnancy rate $=+4 \mathrm{~d}$ open; VanRaden et al., 2004). Although reproduction traits generally exhibit low heritability (Seykora and McDaniel, 1983; Pryce et al., 1997; Kadarmideen et al., 2003; Jiang et al., 2017), the genetic antagonism of milk production and fertility, as well as the unfavorable decline in fertility that occurred during genetic selection, showed the importance of genetic contribution to fertility traits (Hansen et al., 1983; Pryce et al., 1997; Lucy, 2001; Kadarmideen et al., 2003; Veerkamp and Beerda, 2007; Walsh et al., 2011; Peñagaricano and Khatib, 2012). In addition, variation in fertility between and within breeds indicated the possibility of improving fertility without severely slowing genetic gain for milk production (Philipsson, 1981; Royal et al., 2000; Lucy, 2001; Cochran et al., 2013), which has been supported by the stabilization and reversal of the declining trend in daughter pregnancy rate since 2003 (Figure 1B), when fertility started to be included in the USDA national genetic evaluation (VanRaden et al., 2004).

Dairy fertility is a complex phenotype affected by many factors that include nutrition, management, environment, and genetics (Butler, 2000; Royal et al., 2000; Roche, 2006; Wathes et al., 2007; Berry et al., 2014). The complex nature of fertility calls for the use of all available resources and tools, including genetic methods, to understand and improve fertility. It has been shown that genetic factors with additive and nonadditive effects contribute to fertility, and sequence-based large sample analysis will lead to the most productive 
genomic discovery and application to improve fertility traits (Daetwyler et al., 2014; Jiang et al., 2017).

Many studies have been conducted to discover causal or tightly linked genetic variants and to apply these genomic discoveries to improve dairy fertility. The genetic components of fertility range from simple monogenic effects of recessive lethal mutations (VanRaden et al., 2011; Kadri et al., 2014) to complex mechanisms that involve multiple genes with additive and nonadditive effects (Wakasugi, 1974; Khatkar, 2004; Huang et al., 2010; Sahana et al., 2010; Peñagaricano et al., 2012).
Current SNP chips have contributed to the successes of genomic selection and to the efforts of discovering genetic variants associated with fertility but offer only limited coverage of genes and the genome. Genome sequence covers all genes and genomic regions that affect fertility and offers the best power to detect fertilityrelated variants and regions and to predict fertility traits (VanRaden et al., 2017). Sequence-based genomic selection can potentially improve accuracy by increasing the linkage disequilibrium between SNP markers and causal mutations, particularly for fertility traits

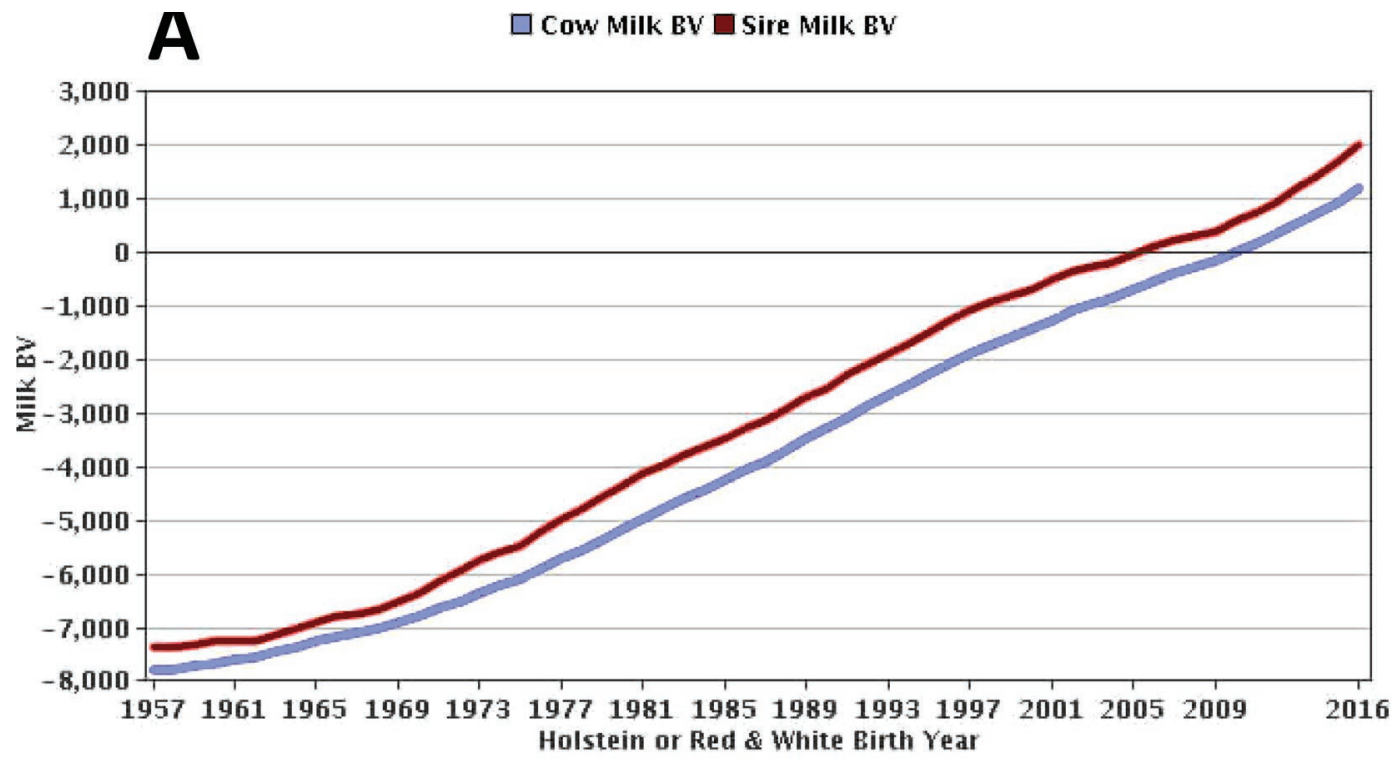

B $\square$ Cow Daughter Preg Rate $\square$ Sire Daughter Preg Rate

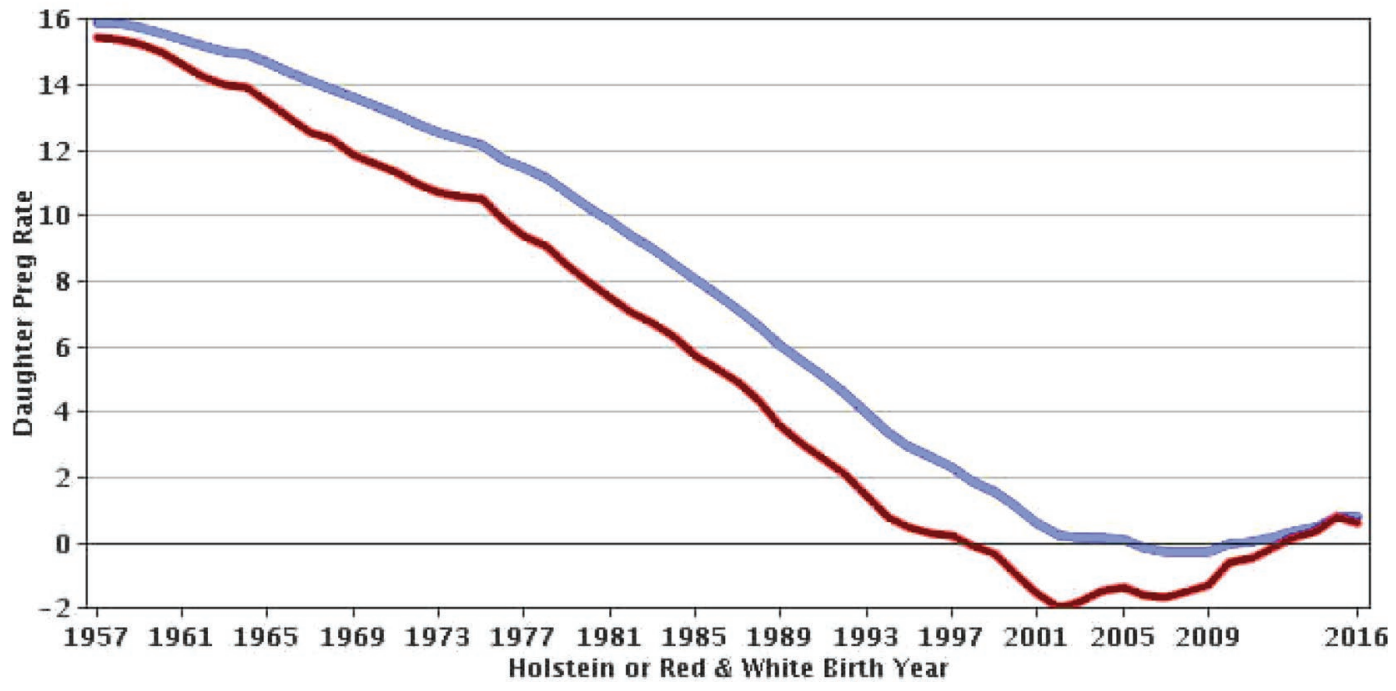

Figure 1. Opposite genetic trends on (A) milk yield and (B) daughter pregnancy (Preg) rate in Holsteins or Red and Whites (Council on Dairy Cattle Breeding, calculated in 2018/4; https://queries.uscdcb.com/eval/summary/trend.cfm). BV = breeding value. 
where causal mutations are of low frequency because of selection (Meuwissen and Goddard, 2010; Clark et al., 2011; Hickey, 2013; Druet et al., 2014; Georges, 2014; MacLeod et al., 2014; VanRaden et al., 2017). Largescale sequence-based association studies are ongoing in humans (1000 Genomes Project Consortium et al., 2012; Morrison et al., 2013; Georgi et al., 2014) and will be the future for livestock animals (Daetwyler et al., 2014; Georges, 2014; Pausch et al., 2014).

This review provides an overview of the past genetic and genomic studies of fertility and related traits in dairy cattle, including descriptions of fertility traits and their heritabilities, genome-wide association studies (GWAS), correlations of fertility with other traits, and genetic and genomic selection of dairy fertility traits.

\section{OVERVIEW OF FERTILITY TRAITS IN DAIRY CATTLE}

Fertility in dairy cattle is a complex phenotype affected by many factors involving the entire reproductive cycle from conception to calving and genetics in both sexes (Ayalon, 1978; Diskin and Morris, 2008). Although reproductive records can be largely affected by management decisions, the dairy industry and researchers have been devoted to developing accurate fertility traits in the past $20 \mathrm{yr}$ (VanRaden et al., 2004; Jorjani, 2006; Cole et al., 2007).

\section{Fertility Traits Exchanged by Interbull}

Since 2007, Interbull (Uppsala, Sweden) has combined national evaluations of female fertility traits from many populations (Jorjani, 2006), including 20 participating countries as of April 2018. Trait definitions often differ across countries and are grouped into 5 common traits exchanged internationally: (1) maiden heifer's ability to conceive, (2) interval from calving to first insemination or estrus, (3) cow conception rate, (4) cow conception interval, and (5) interval from calving to conception, calving interval, or days open. Precise definitions of the trait definitions, edits, and calculation methods from each country are documented by Interbull, and each participating country receives the combined multitrait across-country evaluations of bulls from all participants.

\section{Fertility and Related Traits in the United States}

The USDA Animal Genomics and Improvement Laboratory (AGIL; Beltsville, MD) and Council on Dairy Cattle Breeding (Bowie, MD) have developed a comprehensive set of US fertility traits covering the whole reproductive cycle, including daughter pregnancy rate, heifer and cow conception rates, sire conception rate, sire and dam stillbirth, sire and dam calving ease, gestation length, age at first calving, and calving to first insemination (Table 1). These phenotypes have been routinely collected by the DHIA (Verona, WI) using methods approved by the International Committee for Animal Recording (Rome, Italy; Egger-Danner et al., 2013). Genomic predictions include the national phenotypes plus the multitrait across-country evaluation fertility data from Interbull.

The US fertility traits cover the main components of reproduction: cycling, conceiving, embryo survival, and calving. Conception is measured by heifer, cow, and sire conception rates. Cycling is measured by calving to first insemination and included in daughter pregnancy rate. Embryo survival is also included in daughter pregnancy rate. Calving includes stillbirth and calving difficulty effects from the calf's sire and maternal

Table 1. Fertility and related traits evaluated in the United States

\begin{tabular}{|c|c|c|}
\hline Phenotype & Description & $\begin{array}{l}\text { Heritability } \\
\text { in Holstein }\end{array}$ \\
\hline $\begin{array}{l}\text { Conception rate (heifer, cow, } \\
\text { and sire; } 3 \text { traits) }\end{array}$ & $\begin{array}{l}\text { Heifer, lactating cow, and sire's ability/contribution to conceive defined as percentage } \\
\text { pregnancy at each service (Taylor et al., 1985; Kuhn and Hutchison, 2008; Albarrán- } \\
\text { Portillo and Pollott, 2013; Galvão et al., 2013) }\end{array}$ & 0.5 to $\sim 8 \%$ \\
\hline Daughter pregnancy rate & $\begin{array}{l}\text { Percentage of cows that become pregnant during each 21-d period (VanRaden et al., 2004; } \\
\text { Parker Gaddis et al., 2014) }\end{array}$ & 3 to $\sim 5 \%$ \\
\hline Calving to first insemination & $\begin{array}{l}\text { Cow's ability to start cycling defined as days from calving to first insemination (Shannon } \\
\text { et al., 1952) }\end{array}$ & 6 to $\sim 10 \%$ \\
\hline $\begin{array}{l}\text { Calving ease (service sire } \\
\text { and daughter; } 2 \text { traits) }\end{array}$ & $\begin{array}{l}\text { Percentage of births that are difficult; sire and daughter calving ease measures tendency } \\
\text { of calves from a service sire and cow to be born (Mwaanga and Janowski, 2000; Cole et } \\
\text { al., 2007) }\end{array}$ & 2 to $\sim 5 \%$ \\
\hline Age at first calving & $\begin{array}{l}\text { Expressed as the age of first calving calculated from birth dates; age at first calving } \\
\text { encompasses puberty and ability to conceive, gestate, and deliver a calf (Gill and Allaire, } \\
\text { 1976; Hutchison et al., 2017a) }\end{array}$ & 6 to $\sim 10 \%$ \\
\hline
\end{tabular}


grandsire. Gestation length is another fertility-related trait. These fertility traits measure the separate contributions of sire and dam. Recessive haplotypes affecting fertility and genomic inbreeding coefficients for each potential male-female mating are also reported (Sun et al., 2013). Breeders use these to reduce harmful genetic interactions of sire and dam that directly affect the embryo.

\section{Low Heritability of Fertility Traits}

It is generally accepted that fertility traits have low heritability (Weller and Ron, 1992; Boichard and Manfredi, 1994; Pryce et al., 1997; Lucy, 2001; Kadarmideen et al., 2003; Veerkamp and Beerda, 2007; Walsh et al., 2011; Peñagaricano and Khatib, 2012; Peñagaricano et al., 2012). The low heritability of fertility traits (Table 1) may involve many contributing factors, including the genetic and biological complexity of fertility, difficulty and inaccuracy in the measurement of fertility traits, and the strong correlation with fitness and reproduction (Merilä and Sheldon, 1999; Mackay, 2001). Many fertility traits are difficult to measure and are largely affected by management decisions, including days open, that highly correlate with conception and pregnancy rates. In addition, mutations or variants of fertility are kept at low frequency because of natural selection on fitness-related traits, thereby leading to smaller genetic variation and heritability of fertilityrelated traits (Slatkin, 1985; Merilä and Sheldon, 1999; Mackay, 2001; Bamshad and Wooding, 2003). This lowfrequency QTL hypothesis for fertility is also supported by the identification of several low-frequency embryonic lethal haplotypes by the researchers at USDA-AGIL (VanRaden et al., 2011; Sonstegard et al., 2013; McClure et al., 2014). However, the differences in fertility between and within cattle breeds, as well as the difference between contemporary Holsteins and those of $50 \mathrm{yr}$ ago, suggest the existence of genetic variation underlying dairy fertility and imply the possibility of improving the genetic component of fertility without severely slowing genetic gain for milk production (VanRaden et al., 2004; Cochran et al., 2013). In addition to DNA variations, other related determinants of fertility traits have been investigated, including transcriptome, methylation, and microbiomes (Veerkamp and Beerda, 2007; Williams, 2013; Kropp et al., 2017).

\section{GWAS OF FERTILITY TRAITS}

Together with the implementation of genomic evaluation, GWAS have been conducted to discover hundreds of genomic regions and candidate genes associated with diverse traits in many cattle populations ( $\mathrm{Hu}$ et al., 2016). Cattle GWAS, especially for dairy cattle, have several unique features compared with other species. First, cattle have a small effective population size (hundreds) and therefore high level of linkage disequilibrium across the cattle genome (Hayes et al., 2003). Second, due to the high linkage disequilibrium between SNP, cattle GWAS can have a higher statistical power but lower precision. Third, cattle GWAS often use genetic merit as phenotype, which is much more accurate than single phenotypic records in humans. Fourth, cattle populations are closely related due to the intensive use of AI with influential bulls, and hence different cattle GWAS studies had less independence between them.

\section{Review of 295 Published Cattle GWAS}

With these unique features of cattle GWAS and the low heritability of fertility traits, we aim to review a few most powerful GWAS of dairy fertility traits. We manually checked 295 references of cattle GWAS published from 1996 to 2018 that are collected in the CattleQTLdb (Hu et al., 2016). Focusing on Holstein cows, we selected 8 publications that studied female fertility traits (Table 2). These studies can be powerful with a sample size of thousands of cows or bulls for cattle GWAS. For this review, we summarize the associated genomic regions across 8 different studies, report the most promising QTL and genes related to dairy fertility, and investigate the effects of these associated loci on different dairy traits. This review provides information on the genetic correlation between fertility and other traits and elucidates the selection pressures on these major fertility QTL.

\section{Underpowered GWAS for Fertility Traits}

Although male fertility and female maturation have just started to be included in the cattle GWAS (Taylor et al., 2018), most of the past studies we reviewed used conception- and calving-related traits in cows (Table 2 ). Different from dairy production traits, GWAS of fertility traits tend to be underpowered and have difficulty finding major QTL shared across studies (Table 3). Using a strict genome-wide significance level, only 1 QTL on BTA18 was identified across studies. The 8 GWAS with relatively large sample sizes mostly reported study-specific QTL of fertility, and some of them found no positive results. This is consistent with the low heritability of fertility and the complex nature of fertility traits that are often influenced by management decisions. Considering the low power and differences between these GWAS studies, these study-specific 
Table 2. Summary of genome-wide association studies of female fertility traits in Holsteins

\begin{tabular}{|c|c|c|c|c|c|}
\hline Study & Year & Sample size & Traits & Population & Reference \\
\hline 2 & 2010 & 2,531 bulls & 11 fertility traits & Danish and Swedish & Sahana et al. (2010) \\
\hline 3 & 2011 & 1,654 cows & 5 calving and fertility traits & USDA database & Cole et al. (2011) \\
\hline 5 & 2013 & 2,093 bulls & 5 calving and fertility traits & Italian & Minozzi et al. (2013) \\
\hline 6 & 2016 & 24,000 bulls and 36,000 cows & 3 fertility traits & US database & Parker Gaddis et al. (2016) \\
\hline 7 & 2017 & 4,841 bulls & 10 calving traits & Canadian & Abo-Ismail et al. (2017) \\
\hline
\end{tabular}

QTL can still be valid but are located across several chromosomes, including BTA 1, 3, 5, 6, 7, 8, 12, 20, and 26 (Table 3).

\section{Major Fertility QTL on BTA18}

Five out of 8 studies found the QTL on BTA18 to be significantly associated with fertility traits. This QTL has the largest effect on net merit, a composite trait measuring the final genetic value of an animal, in the US genomic evaluation. More importantly, this QTL is associated with a range of fertility traits from conception to calving as well as body conformation traits (Table 3). Although this QTL has been detected by several studies, the causative gene or mutation is still missing. A few candidate genes are located in this QTL region, including clusters of sialic acid binding Ig-like lectin genes and zinc finger protein genes; however, several studies have failed to conclusively identify the causal genetic variant (Cole et al., 2009; Seidenspinner et al., 2009; Purfield et al., 2015; Mao et al., 2016; Müller et al., 2017). Future studies are still needed to pinpoint the candidate genes and mutations underlying this large QTL on fertility. Cole et al. (2009) also suggested that the pleiotropic effects of this QTL may originate from the effect on embryo development and growth, which would result in this QTL having opposite effects on production and reproduction. These antagonistic effects can put this QTL under balancing selection to maintain intermediate frequency, resulting in a major QTL of fertility in the cattle population. This mechanism of generating major QTL is similar to the well-known gene DGAT1 that has opposite effects on protein and fat.

Table 3. Top SNP in the QTL passing genome-wide significance in 8 genome-wide association studies of female fertility

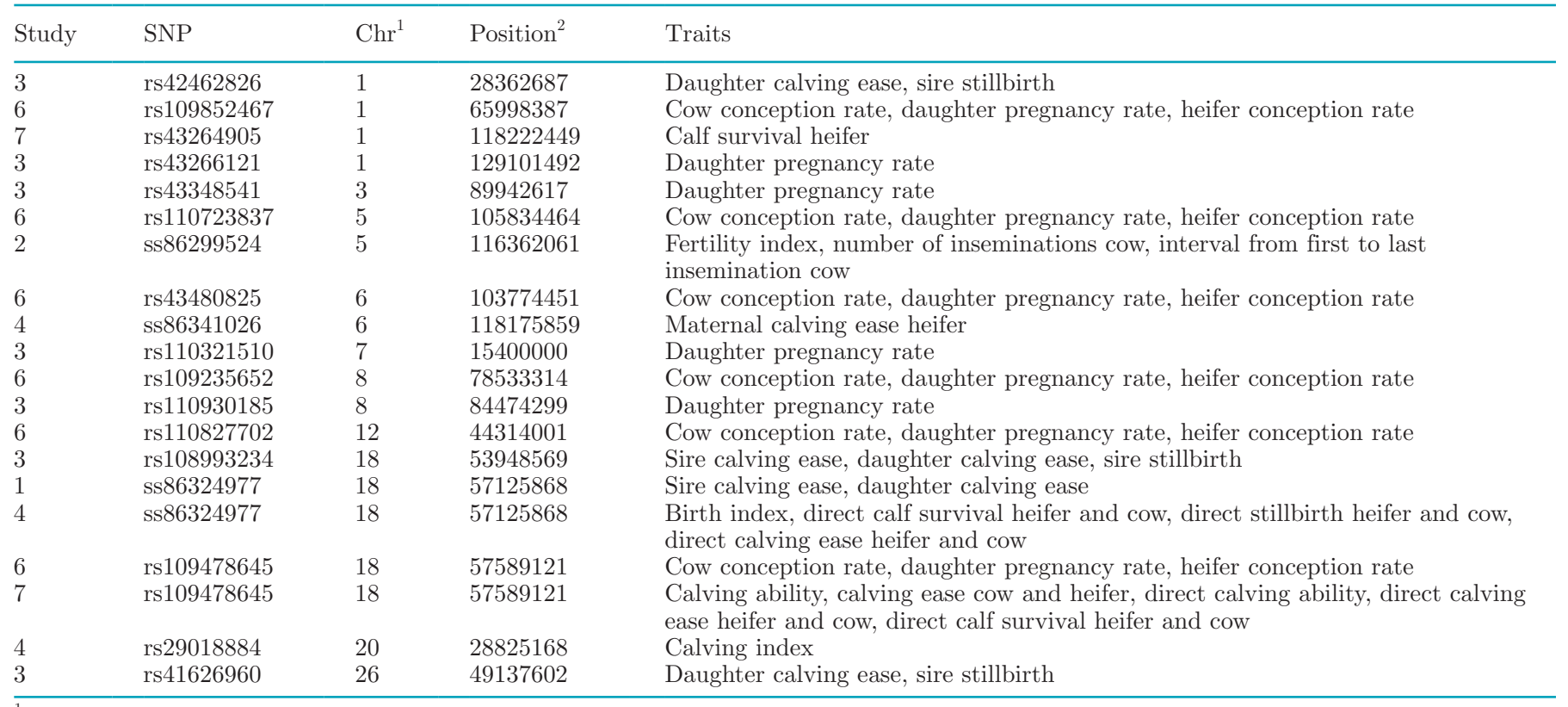

${ }^{1}$ Chromosome.

${ }^{2}$ Chromosomal position on UMD 3.1.1 (http://bovinegenome.org/?q=node/61). 
A
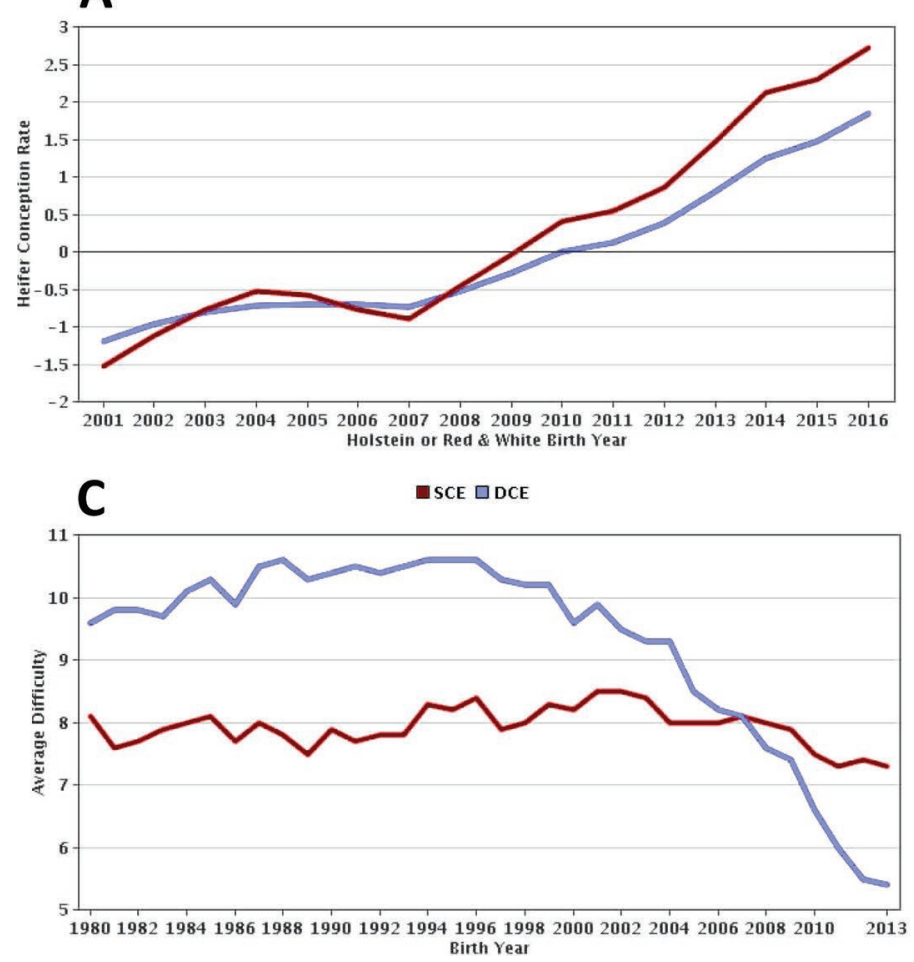

B $\square$ Cow Cow Conception Rate $\mathbf{m}$ Sire Cow Conception Rate

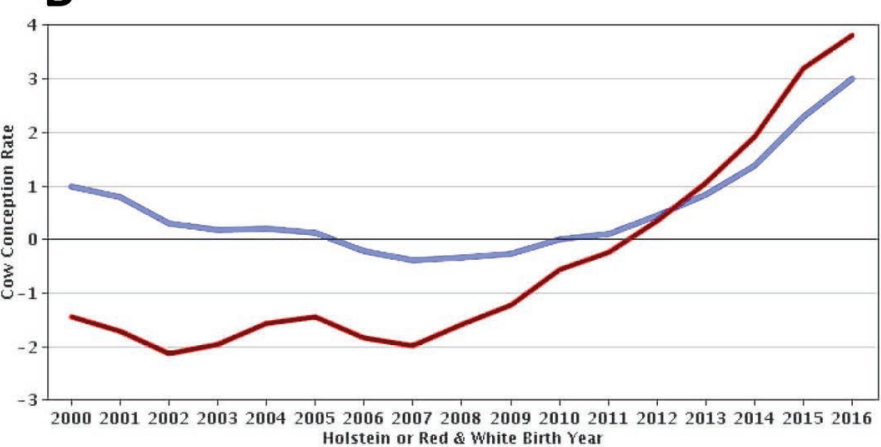

Holstein or Red \& White Birth Year

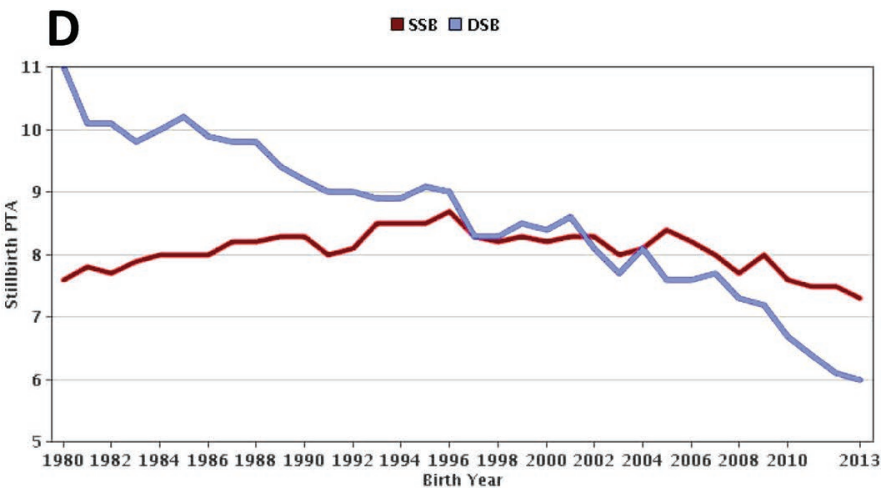

Figure 2. Genetic trends on (A) heifer conception rate, $(\mathrm{B})$ cow conception rate, $(\mathrm{C})$ calving ease $(\mathrm{SCE}=$ sire calving ease; $\mathrm{DCE}=$ daughter calving ease), and (D) stillbirth (SSB = sire stillbirth; DSB = daughter stillbirth) in Holsteins or Red and Whites (Council on Dairy Cattle Breeding, calculated in 2018/4; https://queries.uscdcb.com/eval/summary/trend.cfm).

\section{GENOMIC IMPROVEMENT OF FERTILITY TRAITS IN US DAIRY CATTLE}

Whereas GWAS focus on the large QTL of fertility, genomic selection of fertility traits uses all QTL (SNP) in the genome. Therefore, genomic selection can still be effective for traits with low heritability, such as fertility, compared with GWAS. With a continuously decreasing cost of genotyping, genomic selection provides a better return on investment, especially for large producers. This trend of more large producers adopting genomics technology has been observed in the US dairy industry. Before 2002, US genomic selection primarily focused on dairy production traits, which resulted in an undesired decline in fertility (Figure 1). Since then, fertility traits have been added to the US genomic evaluation: calving ease in 2002, daughter pregnancy rate in 2003, stillbirth in 2006, and cow and heifer conception rates in 2010. With these fertility traits implemented in the selection system, desired changes have been obtained in the Holstein population (Figure 2). These positive responses to selection on fertility traits support the efficiency of genomic selection, even for low-heritable traits. In addition, since the recessive lethal haplotypes were first identified by VanRaden et al. (2011), these deleterious mutations have been routinely scanned and removed from the dairy population (Cooper et al., 2014; Biffani et al., 2015; Biscarini et al., 2016; Schütz et al., 2016), which can help further increase the fertility of dairy cattle. Despite the success of genomic selection in improving economically important traits in dairy cattle, there are potential negative effects of genomic selection, including the hindrance of developing resilient cattle and loss of diversity, that may negatively affect the long-term selection responses (Notter, 1999; Hayes et al., 2009).

\section{Recent Research Progress}

The USDA-ARS AGIL as the center for US dairy genetic evaluations is devoted to genetically improving dairy profitability including fertility (http://aipl .arsusda.gov/). To date, AGIL has developed successful research programs from genomic selection to GWAS in dairy cattle. Here, we review a few recent research developments related to fertility. The current selection index named "net merit" assigns approximately $10 \%$ weighting for 3 conception rates (https://aipl.arsusda .gov/reference/nmcalc-2018.htm). Evaluations for more traits allow producers with different fertility manage- 
ment to select for different traits. For example, cycling is more important with natural heat detection, whereas conception rate is more important with timed AI. More dairy producers are breeding their poor females to beef bulls, allowing Angus bulls to be ranked for fertility (Hutchison et al., 2017b). Age at first calving combines heifer growth and fertility and is automatically recorded in all DHI data. After evaluating the benefit of this new trait, AGIL is currently working on adding age at first calving to the genomic evaluation (Hutchison et al., 2017a). More recent research supports the existence of genetic contributions to superovulation, in vitro fertilization, and embryo transfer in Holstein cattle (Parker Gaddis et al., 2017). Sire conception rate is widely used but poorly understood because it changes across the bull's life. More research has been done to evaluate sire conception rate for heifer and cow inseminations with conventional and sexed semen (Norman et al., 2011). The breeding value of gestation length has been newly calculated to help with fertility management. Spontaneous abortions observed between 152 and $250 \mathrm{~d}$ of gestation have been recorded in DHI for decades but have not been genetically evaluated as a separate trait (Norman et al., 2012). Twinning rate is also not evaluated yet, but twin births have been reported along with calving ease and stillbirth data for decades. Recombination rate has been shown to be heritable with several major QTL identified (Ma et al., 2015). Thus, a more detailed understanding of the genetic factors that affect fertility will be possible in the near future.

\section{CONCLUSIONS}

Fertility traits are complex with low to moderate heritability, especially for conception records that are impeded by management decisions. Current GWAS of fertility traits tend to be underpowered, highlighting the need for continuous data collection to enable larger and more powerful studies. Despite the low power of most GWAS, a major QTL on BTA18 associated with a spectrum of fertility traits was identified by multiple studies; however, future research is still needed to pinpoint the underlying genes and mutations. More importantly, the recent genomic selection on fertility traits has successfully reversed the declining trends on dairy fertility, indicating that genetic improvement of fertility traits is possible even though fertility has low heritability.

\section{ACKNOWLEDGMENTS}

This research was supported in part by Agriculture and Food Research Initiative grant no. 2016-6701524886 from the USDA National Institute of Food and
Agriculture (Washington, DC) and grant no. US-499717 from the US-Israel Binational Agricultural Research and Development Fund (Rishon LeZion, Israel). JBC and PMV were also supported by appropriated projects 1265-31000-096-00, "Improving Genetic Predictions in Dairy Animals Using Phenotypic and Genomic Information," and 8042-31000-104-00, "Enhancing Genetic Merit of Ruminants Through Genome Selection and Analysis," of the Agricultural Research Service of the USDA (Washington, DC), respectively. Mention of trade names or commercial products in this article is solely for the purpose of providing specific information and does not imply recommendation or endorsement by the USDA. The funders had no role in study design, data collection and analysis, decision to publish, or preparation of the manuscript.

\section{REFERENCES}

Abo-Ismail, M. K., L. F. Brito, S. P. Miller, M. Sargolzaei, D. A. Grossi, S. S. Moore, G. Plastow, P. Stothard, S. Nayeri, and F. S. Schenkel. 2017. Genome-wide association studies and genomic prediction of breeding values for calving performance and body conformation traits in Holstein cattle. Genet. Sel. Evol. 49:82.

Albarrán-Portillo, B., and G. Pollott. 2013. The relationship between fertility and lactation characteristics in Holstein cows on United Kingdom commercial dairy farms. J. Dairy Sci. 96:635-646.

Ayalon, N. 1978. A review of embryonic mortality in cattle. J. Reprod. Fertil. 54:483-493.

Bamshad, M., and S. P. Wooding. 2003. Signatures of natural selection in the human genome. Nat. Rev. Genet. 4:99-111.

Berry, D., E. Wall, and J. Pryce. 2014. Genetics and genomics of reproductive performance in dairy and beef cattle. Animal 8(Suppl. 1):105-121.

Biffani, S., C. Dimauro, N. Macciotta, A. Rossoni, A. Stella, and F. Biscarini. 2015. Predicting haplotype carriers from SNP genotypes in Bos taurus through linear discriminant analysis. Genet. Sel. Evol. 47:4.

Biscarini, F., H. Schwarzenbacher, H. Pausch, E. L. Nicolazzi, Y. Pirola, and S. Biffani. 2016. Use of SNP genotypes to identify carriers of harmful recessive mutations in cattle populations. BMC Genomics 17:857.

Boichard, D., and E. Manfredi. 1994. Genetic analysis of conception rate in French Holstein cattle. Acta Agric. Scand. A Anim. Sci. 44:138-145.

Burfening, P., D. Kress, R. Friedrich, and D. Vaniman. 1978. Phenotypic and genetic relationships between calving ease, gestation length, birth weight and preweaning growth. J. Anim. Sci. 47:595-600.

Butler, W. R. 2000. Nutritional interactions with reproductive performance in dairy cattle. Anim. Reprod. Sci. 60-61:449-457.

Clark, S. A., J. M. Hickey, and J. H. Van der Werf. 2011. Different models of genetic variation and their effect on genomic evaluation. Genet. Sel. Evol. 43:18.

Cochran, S. D., J. B. Cole, D. J. Null, and P. J. Hansen. 2013. Discovery of single nucleotide polymorphisms in candidate genes associated with fertility and production traits in Holstein cattle. BMC Genet. 14:49.

Cole, J. B., P. VanRaden, J. O'Connell, C. Van Tassell, T. Sonstegard, R. Schnabel, J. Taylor, and G. Wiggans. 2009. Distribution and location of genetic effects for dairy traits. J. Dairy Sci. 92:2931-2946.

Cole, J. B., G. Wiggans, P. VanRaden, and R. Miller. 2007. Stillbirth (co) variance components for a sire-maternal grandsire threshold model and development of a calving ability index for sire selection. J. Dairy Sci. 90:2489-2496. 
Cole, J. B., G. R. Wiggans, L. Ma, T. S. Sonstegard, T. J. Lawlor, B. A. Crooker, C. P. Van Tassell, J. Yang, S. Wang, and L. K. Matukumalli. 2011. Genome-wide association analysis of thirty one production, health, reproduction and body conformation traits in contemporary US Holstein cows. BMC Genomics 12:408.

1000 Genomes Project Consortium, G. R. Abecasis, A. Auton, L. D. Brooks, M. A. DePristo, R. M. Durbin, R. E. Handsaker, H. M. Kang, G. T. Marth, and G. A. McVean. 2012. An integrated map of genetic variation from 1,092 human genomes. Nature 491:56-65.

Cooper, T. A., G. Wiggans, D. Null, J. Hutchison, and J. Cole. 2014. Genomic evaluation, breed identification, and discovery of a haplotype affecting fertility for Ayrshire dairy cattle. J. Dairy Sci. 97:3878-3882.

Daetwyler, H. D., A. Capitan, H. Pausch, P. Stothard, R. Van Binsbergen, R. F. Brøndum, X. Liao, A. Djari, S. C. Rodriguez, and C. Grohs. 2014. Whole-genome sequencing of 234 bulls facilitates mapping of monogenic and complex traits in cattle. Nat. Genet. 46:858-865.

de Vries, M., and R. Veerkamp. 2000. Energy balance of dairy cattle in relation to milk production variables and fertility. J. Dairy Sci. 83:62-69.

Diskin, M. G., and D. Morris. 2008. Embryonic and early foetal losses in cattle and other ruminants. Reprod. Domest. Anim. 43(Suppl. 2):260-267.

Druet, T., I. Macleod, and B. Hayes. 2014. Toward genomic prediction from whole-genome sequence data: Impact of sequencing design on genotype imputation and accuracy of predictions. Heredity 112:39-47

Egger-Danner, C., J. B. Cole, J. E. Pryce, N. Gengler, B. Heringstad, A. Bradley, and K. F. Stock. 2013. Which new traits are expected to be available in the near future? Interbull Bull. 47:236-245.

Galvão, K. N., P. Federico, A. De Vries, and G. Schuenemann. 2013. Economic comparison of reproductive programs for dairy herds using estrus detection, timed artificial insemination, or a combination. J. Dairy Sci. 96:2681-2693.

García-Ruiz, A., J. B. Cole, P. M. VanRaden, G. R. Wiggans, F. J. Ruiz-López, and C. P. Van Tassell. 2016. Changes in genetic selection differentials and generation intervals in US Holstein dairy cattle as a result of genomic selection. Proc. Natl. Acad. Sci. USA 113:E3995-E4004.

Georges, M. 2014. Towards sequence-based genomic selection of cattle. Nat. Genet. 46:807-809.

Georgi, B., D. Craig, R. L. Kember, W. Liu, I. Lindquist, S. Nasser, C. Brown, J. A. Egeland, S. M. Paul, and M. Bućan. 2014. Genomic view of bipolar disorder revealed by whole genome sequencing in a genetic isolate. PLoS Genet. 10:e1004229

Gill, G., and F. Allaire. 1976. Relationship of age at first calving, days open, days dry, and herdlife to a profit function for dairy cattle. J. Dairy Sci. 59:1131-1139.

Hansen, L. B., A. Freeman, and P. Berger. 1983. Yield and fertility relationships in dairy cattle. J. Dairy Sci. 66:293-305.

Hayes, B. J., P. Bowman, A. Chamberlain, and M. Goddard. 2009 Invited review: Genomic selection in dairy cattle: Progress and challenges. J. Dairy Sci. 92:433-443.

Hayes, B. J., P. M. Visscher, H. C. McPartlan, and M. E. Goddard. 2003. Novel multilocus measure of linkage disequilibrium to estimate past effective population size. Genome Res. 13:635-643.

Hickey, J. M. 2013. Sequencing millions of animals for genomic selection 2.0. J. Anim. Breed. Genet. 130:331-332.

Hu, Z.-L., C. A. Park, and J. M. Reecy. 2016. Developmental progress and current status of the Animal QTLdb. Nucleic Acids Res. 44(D1):D827-D833.

Huang, W., B. Kirkpatrick, G. Rosa, and H. Khatib. 2010. A genomewide association study using selective DNA pooling identifies candidate markers for fertility in Holstein cattle. Anim. Genet. 41:570-578.

Hutchison, J. L., P. VanRaden, D. Null, J. Cole, and D. Bickhart. 2017a. Genomic evaluation of age at first calving. J. Dairy Sci. 100:6853-6861.
Hutchison, J. L., P. M. Van Raden, J. B. Cole, G. C. Fok, and H. D. Norman. 2017b. Bull fertility evaluations for Angus service sires bred to Holstein cows. J. Dairy Sci. 100(Suppl. 2):242 (Abstr.).

Jiang, J., B. Shen, J. R. O'Connell, P. M. VanRaden, J. B. Cole, and L. Ma. 2017. Dissection of additive, dominance, and imprinting effects for production and reproduction traits in Holstein cattle. BMC Genomics 18:425.

Jorjani, H. 2006. International genetic evaluation for female fertility traits. Interbull Bull. 37:144-147.

Kadarmideen, H. N., R. Thompson, M. P. Coffey, and M. A. Kossaibati. 2003. Genetic parameters and evaluations from single- and multiple-trait analysis of dairy cow fertility and milk production. Livest. Prod. Sci. 81:183-195.

Kadri, N. K., G. Sahana, C. Charlier, T. Iso-Touru, B. Guldbrandtsen, L. Karim, U. S. Nielsen, F. Panitz, G. P. Aamand, and N. Schulman. 2014. A 660-kb deletion with antagonistic effects on fertility and milk production segregates at high frequency in Nordic Red cattle: Additional evidence for the common occurrence of balancing selection in livestock. PLoS Genet. 10:e1004049.

Kropp, J., J. A. Carrillo, H. Namous, A. Daniels, S. M. Salih, J. Song, and H. Khatib. 2017. Male fertility status is associated with DNA methylation signatures in sperm and transcriptomic profiles of bovine preimplantation embryos. BMC Genomics 18:280.

Kuhn, M. T., and J. Hutchison. 2008. Prediction of dairy bull fertility from field data: Use of multiple services and identification and utilization of factors affecting bull fertility. J. Dairy Sci. 91:24812492.

Lucy, M. C. 2001. Reproductive loss in high-producing dairy cattle: Where will it end? J. Dairy Sci. 84:1277-1293.

Ma, L., J. R. O'Connell, P. M. VanRaden, B. Shen, A. Padhi, C. Sun, D. M. Bickhart, J. B. Cole, D. J. Null, and G. E. Liu. 2015. Cattle sex-specific recombination and genetic control from a large pedigree analysis. PLoS Genet. 11:e1005387.

Mackay, T. F. 2001. The genetic architecture of quantitative traits. Annu. Rev. Genet. 35:303-339.

MacLeod, I. M., B. J. Hayes, and M. E. Goddard. 2014. The effects of demography and long-term selection on the accuracy of genomic prediction with sequence data. Genetics 198:1671-1684.

Mao, X., N. K. Kadri, J. R. Thomasen, D. De Koning, G. Sahana, and B. Guldbrandtsen. 2016. Fine mapping of a calving QTL on Bos taurus autosome 18 in Holstein cattle. J. Anim. Breed. Genet. 133:207-218.

McClure, M. C., D. Bickhart, D. Null, P. VanRaden, L. Xu, G. Wiggans, G. Liu, S. Schroeder, J. Glasscock, and J. Armstrong. 2014 Bovine exome sequence analysis and targeted SNP genotyping of recessive fertility defects $\mathrm{BH} 1, \mathrm{HH} 2$, and $\mathrm{HH} 3$ reveal a putative causative mutation in SMC2 for HH3. PLoS One 9:e92769.

Merilä, J., and B. C. Sheldon. 1999. Genetic architecture of fitness and nonfitness traits: Empirical patterns and development of ideas. Heredity 83:103-109.

Meuwissen, T., and M. Goddard. 2010. Accurate prediction of genetic values for complex traits by whole-genome resequencing. Genetics 185:623-631.

Minozzi, G., E. L. Nicolazzi, A. Stella, S. Biffani, R. Negrini, B. Lazzari, P. Ajmone-Marsan, and J. L. Williams. 2013. Genome wide analysis of fertility and production traits in Italian Holstein cattle. PLoS One 8:e80219.

Morrison, A. C., A. Voorman, A. D. Johnson, X. Liu, J. Yu, A. Li, D. Muzny, F. Yu, K. Rice, and C. Zhu. 2013. Whole genome sequencebased analysis of a model complex trait, high density lipoprotein cholesterol. Nat. Genet. 45:899-901.

Müller, M.-P., S. Rothammer, D. Seichter, I. Russ, D. Hinrichs, J. Tetens, G. Thaller, and I. Medugorac. 2017. Genome-wide mapping of 10 calving and fertility traits in Holstein dairy cattle with special regard to chromosome 18. J. Dairy Sci. 100:1987-2006.

Mwaanga, E., and T. Janowski. 2000. Anoestrus in dairy cows: Causes, prevalence and clinical forms. Reprod. Domest. Anim. 35:193-200.

Nayeri, S., M. Sargolzaei, M. Abo-Ismail, S. Miller, F. Schenkel, S. Moore, and P. Stothard. 2017. Genome-wide association study for 
lactation persistency, female fertility, longevity, and lifetime profit index traits in Holstein dairy cattle. J. Dairy Sci. 100:1246-1258.

Norman, H. D., J. Hutchison, and P. VanRaden. 2011. Evaluations for service-sire conception rate for heifer and cow inseminations with conventional and sexed semen. J. Dairy Sci. 94:6135-6142.

Norman, H. D., R. Miller, J. Wright, J. Hutchison, and K. Olson. 2012. Factors associated with frequency of abortions recorded through Dairy Herd Improvement test plans. J. Dairy Sci. 95:4074-4084.

Norman, H. D., J. Wright, M. Kuhn, S. Hubbard, J. Cole, and P. VanRaden. 2009. Genetic and environmental factors that affect gestation length in dairy cattle. J. Dairy Sci. 92:2259-2269.

Notter, D. R. 1999. The importance of genetic diversity in livestock populations of the future. J. Anim. Sci. 77:61-69.

Parker Gaddis, K. L., J. Cole, J. Clay, and C. Maltecca. 2014. Genomic selection for producer-recorded health event data in US dairy cattle. J. Dairy Sci. 97:3190-3199.

Parker Gaddis, K. L., S. Dikmen, D. Null, J. Cole, and P. Hansen. 2017. Evaluation of genetic components in traits related to superovulation, in vitro fertilization, and embryo transfer in Holstein cattle. J. Dairy Sci. 100:2877-2891.

Parker Gaddis, K. L., D. Null, and J. Cole. 2016. Explorations in genome-wide association studies and network analyses with dairy cattle fertility traits. J. Dairy Sci. 99:6420-6435.

Pausch, H., C. Wurmser, C. Edel, R. Emmerling, K. Götz, and R. Fries. 2014. Exploiting whole genome sequence data for the identification of causal trait variants in cattle. Volume methods and tools: Statistical and genomic tools for mapping QTL and genes. Page 191 in Proc. 10th World Congress on Genetics Applied to Livestock Production. ASAS, Vancouver, Canada.

Peñagaricano, F., and H. Khatib. 2012. Association of milk protein genes with fertilization rate and early embryonic development in Holstein dairy cattle. J. Dairy Res. 79:47-52.

Peñagaricano, F., K. Weigel, and H. Khatib. 2012. Genome-wide association study identifies candidate markers for bull fertility in Holstein dairy cattle. Anim. Genet. 43(Suppl. 1):65-71.

Philipsson, J. 1981. Genetic aspects of female fertility in dairy cattle. Livest. Prod. Sci. 8:307-319.

Pryce, J., R. Veerkamp, R. Thompson, W. Hill, and G. Simm. 1997. Genetic aspects of common health disorders and measures of fertility in Holstein Friesian dairy cattle. Anim. Sci. 65:353-360.

Purfield, D. C., D. G. Bradley, R. D. Evans, F. J. Kearney, and D. P. Berry. 2015. Genome-wide association study for calving performance using high-density genotypes in dairy and beef cattle. Genet. Sel. Evol. 47:47.

Khatkar, M. S., P. C. Thomson, I. Tammen, and H. W. Raadsma. 2004. Quantitative trait loci mapping in dairy cattle: Review and meta-analysis. Genet. Sel. Evol. 36:163-190.

Roche, J. F. 2006. The effect of nutritional management of the dairy cow on reproductive efficiency. Anim. Reprod. Sci. 96:282-296.

Royal, M., A. Darwash, A. Flint, R. Webb, J. Woolliams, and G. Lamming. 2000. Declining fertility in dairy cattle: Changes in traditional and endocrine parameters of fertility. Anim. Sci. 70:487-501.

Sahana, G., B. Guldbrandtsen, C. Bendixen, and M. Lund. 2010. Genome-wide association mapping for female fertility traits in Danish and Swedish Holstein cattle. Anim. Genet. 41:579-588.

Sahana, G., B. Guldbrandtsen, and M. S. Lund. 2011. Genome-wide association study for calving traits in Danish and Swedish Holstein cattle. J. Dairy Sci. 94:479-486.
Schütz, E., C. Wehrhahn, M. Wanjek, R. Bortfeld, W. E. Wemheuer, J. Beck, and B. Brenig. 2016. The Holstein Friesian lethal haplotype 5 (HH5) results from a complete deletion of TBF1M and cholesterol deficiency (CDH) from an ERV-(LTR) insertion into the coding region of APOB. PLoS One 11:e0154602.

Seidenspinner, T., J. Bennewitz, F. Reinhardt, and G. Thaller. 2009. Need for sharp phenotypes in QTL detection for calving traits in dairy cattle. J. Anim. Breed. Genet. 126:455-462.

Seykora, A. J., and B. McDaniel. 1983. Heritabilities and correlations of lactation yields and fertility for Holsteins. J. Dairy Sci. 66:1486-1493.

Shannon, F., G. Salisbury, and N. VanDemark. 1952. The fertility of cows inseminated at various intervals after calving. J. Anim. Sci. $11: 355-360$.

Slatkin, M. 1985. Rare alleles as indicators of gene flow. Evolution $39: 53-65$.

Sonstegard, T. S., J. B. Cole, P. M. VanRaden, C. P. Van Tassell, D. J. Null, S. G. Schroeder, D. Bickhart, and M. C. McClure. 2013. Identification of a nonsense mutation in CWC15 associated with decreased reproductive efficiency in Jersey cattle. PLoS One 8:e54872

Sun, C., P. VanRaden, J. O'Connell, K. Weigel, and D. Gianola. 2013. Mating programs including genomic relationships and dominance effects. J. Dairy Sci. 96:8014-8023.

Taylor, J. F., R. Everett, and B. Bean. 1985. Systematic environmental, direct, and service sire effects on conception rate in artificially inseminated Holstein cows. J. Dairy Sci. 68:3004-3022.

Taylor, J. F., R. D. Schnabel, and P. Sutovsky. 2018. Genomics of bull fertility. Animal 12(Suppl. 1):S172-S183.

VanRaden, P. M., K. Olson, D. Null, and J. Hutchison. 2011. Harmful recessive effects on fertility detected by absence of homozygous haplotypes. J. Dairy Sci. 94:6153-6161.

VanRaden, P. M., A. Sanders, M. Tooker, R. Miller, H. Norman, M. Kuhn, and G. Wiggans. 2004. Development of a national genetic evaluation for cow fertility. J. Dairy Sci. 87:2285-2292.

VanRaden, P. M., M. E. Tooker, J. R. O'connell, J. B. Cole, and D. M. Bickhart. 2017. Selecting sequence variants to improve genomic predictions for dairy cattle. Genet. Sel. Evol. 49:32.

Veerkamp, R. F., and B. Beerda. 2007. Genetics and genomics to improve fertility in high producing dairy cows. Theriogenology 68:S266-S273.

Wakasugi, N. 1974. A genetically determined incompatibility system between spermatozoa and eggs leading to embryonic death in mice. J. Reprod. Fertil. 41:85-96.

Walsh, S. W., E. Williams, and A. Evans. 2011. A review of the causes of poor fertility in high milk producing dairy cows. Anim. Reprod. Sci. 123:127-138.

Wathes, D. C., M. Fenwick, Z. Cheng, N. Bourne, S. Llewellyn, D. Morris, D. Kenny, J. Murphy, and R. Fitzpatrick. 2007. Influence of negative energy balance on cyclicity and fertility in the high producing dairy cow. Theriogenology 68:S232-S241.

Weller, J. I., and M. Ron. 1992. Genetic analysis of fertility traits in Israeli Holsteins by linear and threshold models. J. Dairy Sci. $75: 2541-2548$.

Williams, E. J. 2013. Drivers of post-partum uterine disease in dairy cattle. Reprod. Domest. Anim. 48:53-58. 